\title{
sciforum
}

Conference Proceedings Paper

\section{The influence of climate and land-cover scenarios on dam management strategies in a high water pressure catchment in North-east Spain}

\author{
*Zabalza-Martínez, J. ${ }^{1}$, Vicente-Serrano, S.M. ${ }^{1}$, López-Moreno, J.I. ${ }^{1}$, Borràs Calvo, G. ${ }^{2}$, Savé, R. ${ }^{3}$, \\ Pascual, D. ${ }^{4}$, Plá, E. ${ }^{4}$, Morán-Tejeda, E. ${ }^{6}$ and Tague, C.L. ${ }^{5}$ \\ Published: 10/11/2017 \\ Academic Editor: Adriana Cuartas \\ 1 Instituto Pirenaico de Ecología (IPE-CSIC), CSIC, Avda. Montañana 1005, Zaragoza 50.059, Spain \\ 2 Oficina Catalana del Canvi Climàtic (OCCC), Generalitat de Catalunya, Barcelona, Spain \\ IRTA, Environmental Horticulture, Torre Marimon, Caldes de Montbui, Barcelona, Spain \\ Centre de Reserca Ecològica i Aplicacions Forestals (CREAF), Bellaterra, Barcelona, Spain \\ University of Santa Barbara, Bren School of Environmental Science \& Management, CA, USA \\ 6 University of Balearic Islands, Department of Geography, Palma de Mallorca, Spain \\ * Correspondence: jzabalza@ipe.csic.es; Tel.: +34-976-369-393
}

\begin{abstract}
The water management of Boadella-Darnius reservoir (NE Spain) has been analysed for the period 1971-2013 to understand the different strategies applied in the past. Streamflow has been projected under climate conditions included in the Third Report on Climate Change in Catalonia (TCCC) and under land-use change scenarios. We have simulated Darnius-Boadella reservoir inflow (2021-2050) using the Regional Hydro-Ecologic Simulation System (RHESsys) with two objectives: (i) to analyse the impact of climate and land-use changes on the water resources of the basin and (ii) to analyse the different plausible strategies of water management at mid-term period (2021-2050). Results reveal a clear negative trend in dam inflow (-34.7\%) since it was built in 1971. The simulations obtained with RHESsys show a similar trend at mid-term (2021-2050) with $-31.1 \%$ under climate and land-use change conditions. Considering the ecological minimum flow outlined by Catalan Water Agency (ACA) and the possible dam inflow decrease, different water management strategies are needed to mitigate the effects of the expected climate change.
\end{abstract}

Keywords: RHESsys, modelling, streamflow, Climate change, Land-use changes, dam management.

\section{Introduction}

Water resources in the Mediterranean region basin is affected by high pressure by human activities including urban supply [1], irrigation [2,3] and tourism activities [4]. In this region surface runoff and streamflow have dominantly decreased in the past three decades $[1,5]$. Such decrease may be related to an increase of temperatures, between 1 and $1.5{ }^{\circ} \mathrm{C}$ for the Iberian peninsula [6], and to changes in land cover resulting from farmland abandonment [7] and increase in forest density [8]. The impact of a warming process has involved an increment of the atmospheric evaporative demand $[9,10]$ and changes in snow accumulation and melting, facts that also explain the decrease of the streamflow, and the seasonal shifts in streamflow timing [11]. Given the strong climate seasonality in the Mediterranean region in which a strong dry season is recorded in summer coinciding with the 
The 1st International Electronic Conference on Hydrological Cycle (CHyCle-2017), 12 - 16 November 2017;

Sciforum Electronic Conference Series, Vol. 1, 2017

period of higher water demand, water management is a key issue in the region. For this reason, a dense network of hydraulic infrastructures has been created in the past decades to store water and ensuring supply during the demanding periods.

This work shows an approach to assessing the effects of the climate and land-use changes on water resources in a Mediterranean river basin that is highly dependant on freshwater for human activities (mainly tourism and agriculture). The approach includes climate projections developed on the last Third Report on Climate Change in Catalonia (TRCC) [12] under RCP4.5 scenario described in the last IPCC report and under an afforestation scenario described in the project Demonstration and validation of innovative methodology for regional climate change adaptation in the Mediterranean area (LifeMEDACC) (http://medacc-life.eu). Simulations to quantify the changes in the dam inflow for the period 2021-2050 were carried out with an ecohydrological model (RHESsys) that was previously subjected to monthly calibration/validation. Moreover, an analysis of the water management strategies of Boadella-Darnius dam was undertaken, as the latter is the main element for water supply in the basin. The evaluation of the results was focused on determining the consequences of the maintainance of the actual management strategies under the plausible future scenarios on water resources of Boadella-Darnius dam.

\section{Data and methods}

\subsection{Study area}

The study area corresponds to the catchment of the Muga and d'Armera rivers from the headwaters to the Darnius-Boadella dam $(183.76 \mathrm{~km} 2)$. It is located in the Northeast Spain, near of the Mediterranean Sea and close the boundary with France (Figure 1, red border), and the dam collects and store most of the water used in the rest of the Muga basin (grey color). The streamflow regime of the river is clearly pluvio-nival, characterized by a short and low snow retention, highflows during March-May and low river discharges in summer. The the highest flows are recorded in autumn due to the high rainfall events that characterizes the basin (Figure 1b). The total annual mean precipitation recorded in Darnius meteorological station (Figure 1a, yellow) is $634 \mathrm{~mm} \mathrm{yr}^{-1}$ (65\% recorderd in spring and autumn) and the mean annual temperature is $15.3^{\circ} \mathrm{C}$. The streamflow is registered in two gauge stations along Muga river, Boadella and Castelló d'Empúries (Figure 1a, white) and the Boadella dam inflow/outflow since its construction in 1971. 
The 1st International Electronic Conference on Hydrological Cycle (CHyCle-2017), 12 - 16 November 2017; Sciforum Electronic Conference Series, Vol. 1, 2017
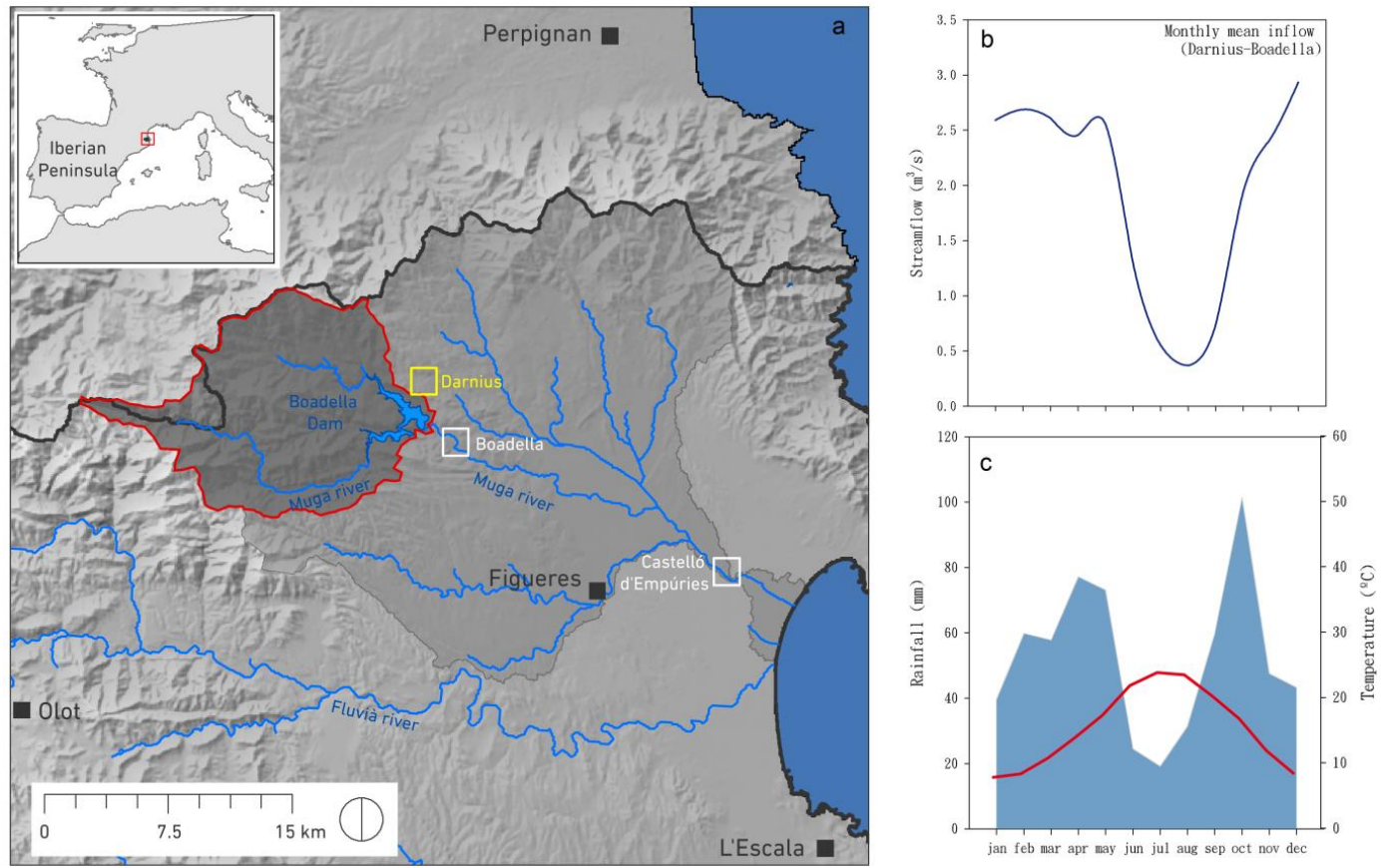

Figure 1. (a) Study area; (b) Monthly mean inflow in Darnius-Boadella dam; (c) Ombroclimatic diagram.

The basin is forested and dominated by Evergreen Broadleaf Forest [EBF], mainly represented by Quercus ilex and Quercus suber (58.4\%), the 19.6\% is occupied by Evergreen Needle Forest [ENF] (Pinus halepensis, Pinus sylvestris and Pinus nigra) and the Broadleaf Deciduous Forest [DBF] (Fagus sylvatica and Castanea sativa) occupies around $14 \%$. The rest of the basin presents some Cropland spots (2.3\%) around the Urban areas $(0.4 \%)$ and along Muga river, Boadella-Darnius dam and other water bodies $(1.9 \%)$, Shrubland $(3.2 \%)$ and areas with no vegetation (0.4\%) (Figure 2 ).

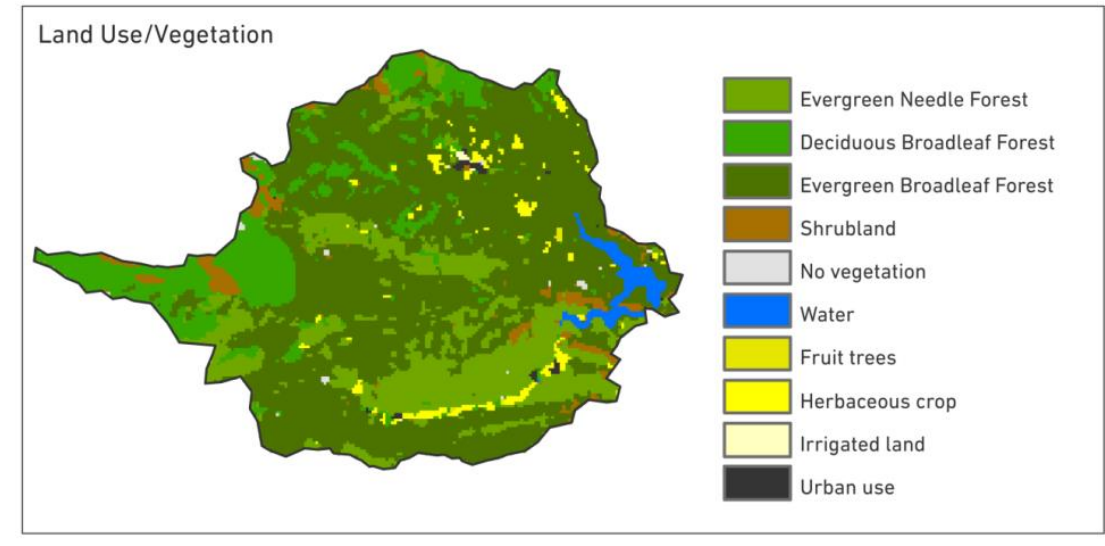

Figure 2.: Actual Land-use scenario

\subsection{Climatic and hydrological data}

Daily precipitation and temperature data from available meteorological stations in the basin were obtained from the Spanish Meteorological Agency (AEMET). We selected the Darnius station as it presents the most complete data series amongst the stations in the study domain (see location in Figure 1) for the period 2001-2011. We also used projected daily maximum and minimum temperature (maximum-minimum) and precipitation for the period 2012-2050 according to the 
The 1st International Electronic Conference on Hydrological Cycle (CHyCle-2017), 12 - 16 November 2017; Sciforum Electronic Conference Series, Vol. 1, 2017

scenarios changes generated in the Third Report of Climate Change report of in Catalonia (TICCC) [12]. The series were generated according [13], based on a combination of series from adjacent stations, filling them with the nearest observatories with a strict quality control to identify rare extremes and to detect inhomogeneity periods. TICCC is based on the RPC 4.5 scenario from the IPCC models [14] and based on a downscaling approach. It predicts an average increase in annual temperature increase of $0.8{ }^{\circ} \mathrm{C}$ and $1.4{ }^{\circ} \mathrm{C}$ for 2012-21 and 2031-2050 periods respectively. Projected changes in average annual precipitation are expected to be around $-2.4 \%$ and $-6.8 \%$ for the related periods. Data inflow of Darnius-Boadella reservoir for 1971-2011 was considered as reference data to calibrate the RHESsys model. It was provided by the Catalan Water Agency of Catalonia (Agencia Catalana del AiguaCA).

\subsection{Spatial data}

The Digital Elevation Model (DEM) was provided by the Catalan Government (Cartographic and Geologic Institute of Catalonia). A Land Cover map has been developed based on the Land Cover Map of Catalonia (MSCS) at the spatial scale of 1:50.000 (Figure 2). The Spanish Land-use System (SIOSE) was used to enrich the MCSC information. In order to simplify the legend, we unified and reclassified the different thematic information. A soil map has been generated by Interfase Research Group of the Geography Department (Autonomous University of Barcelona) using some sources of soil information as: Soils Map of Catalonia, European Soils Map, Data from soil profiles from specific studies and the European Soils Database [15, 16], Geologic Map of Catalonia, Digital Elevation Map and Carbon Content Map in forestal soils of Spain. Land cover scenario for three time windows (20212030, 2031-2040 and 2041-2050) were developed, based on the expected evolution of revegetation within the study area: ENF substitution by EDF and Shrubland by ENF. Optimum areas for EDF and ENF cover types were selected with a multi-criteria analysis (MCA) technique under orographic criteria defined in Ecologic and Forest Inventory of Catalonia [17] (Figure 3).

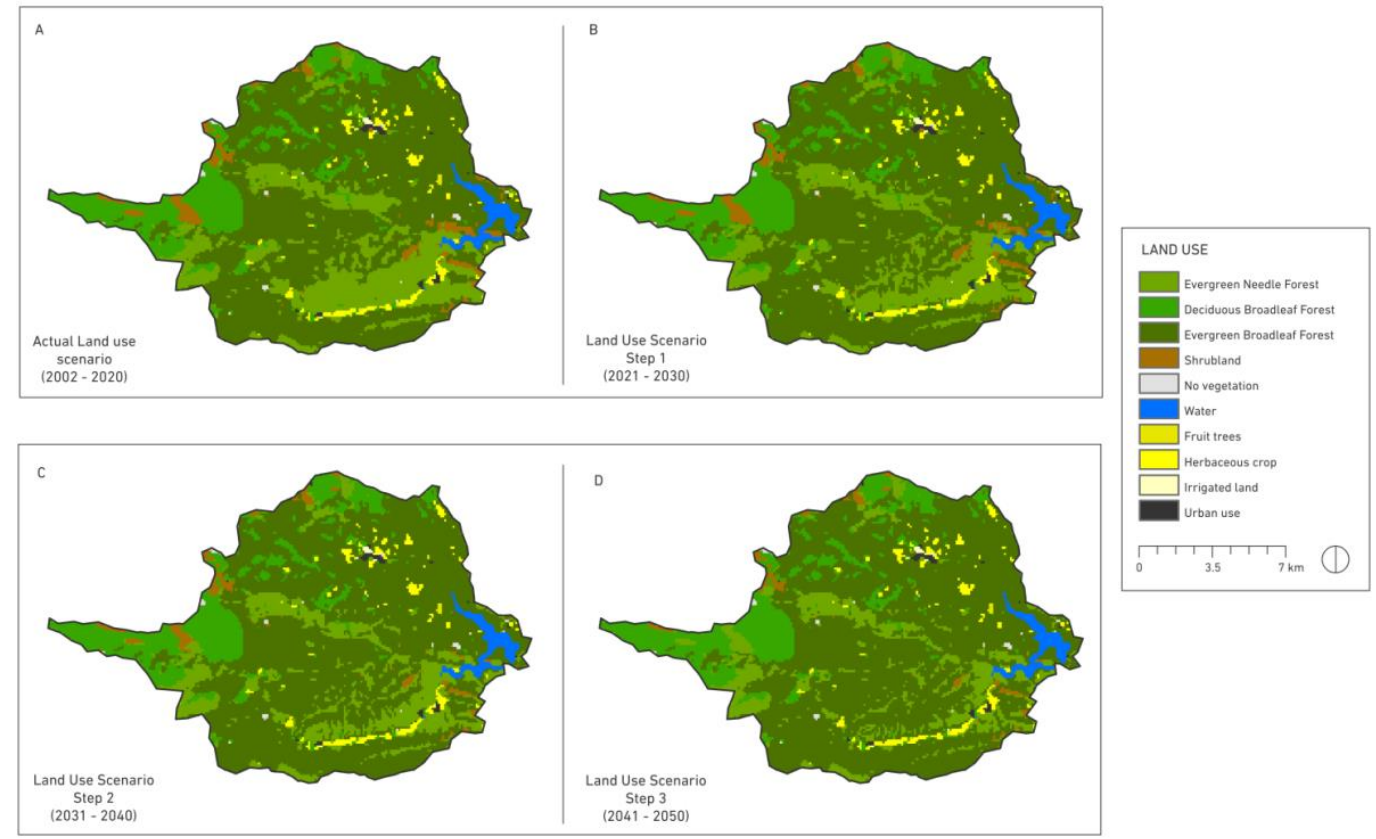

Figure 3. Land-use change evolution 2002-2050.

The elevation, aspect and slope maps were reclassified in groups of cells where is more probable to find each land cover type according to IEFC. The results were combined to get optimum areas for EDF and were substituted gradually if the actual land cover was ENF. The same process was applied for the transition from Shrubland to ENF. Following these parameters of change, a land-use 
The 1st International Electronic Conference on Hydrological Cycle (CHyCle-2017), 12 - 16 November 2017; Sciforum Electronic Conference Series, Vol. 1, 2017

reclassification has been made only for the study area. The surfaces, percentages and their differences are shown in Table 1.

\begin{tabular}{lc|cc|cc|cc}
\cline { 3 - 7 } & \multicolumn{2}{c}{} & \multicolumn{2}{c|}{ R.L.U. 2021-2030 } & \multicolumn{2}{c|}{ R.L.U. 2031-2040 } & \multicolumn{2}{c}{ R.L.U. 2041-2050 } \\
\hline Land-use & A.L.U. $\left(\mathrm{km}^{2}\right)$ & Area $\left(\mathrm{km}^{2}\right)$ & Variation $(\%)^{*}$ & Area $\left(\mathrm{km}^{2}\right)$ & Variation $(\%) *$ & Area $\left(\mathrm{km}^{2}\right)$ & Variation $(\%) *$ \\
\hline Urban use & 0.8 & 0.8 & 0 & 0.8 & 0 & 0.8 & 0 \\
Cropland & 4.2 & 4.2 & 0 & 4.2 & 0 & 4.2 & 0 \\
ENF & 36.2 & 32 & -2.3 & 29.3 & -3.8 & 25.5 & -5.8 \\
BDF & 25.5 & 25.5 & 0 & 25.5 & 0 & 25.5 & 0 \\
EDF & 107.2 & 111.8 & 2.5 & 116.2 & 4.9 & 121.3 & 7.6 \\
Shrubland & 5.8 & 5.5 & -0.2 & 3.8 & -1.1 & 2.5 & -1.8 \\
Water & 3.4 & 3.4 & 0 & 3.4 & 0 & 3.4 & 0 \\
No vegetation & 0.5 & 0.5 & 0 & 0.5 & 0 & 0.5 & 0 \\
\hline
\end{tabular}

Table 1. Area of each scenario (Actual Land-use - A.L.U. and Revegetation Land-use - R.L.U.) and variation

(\%) respect to A.L.U.

\subsection{Regional Hydro-Ecological Simulation System (RHESsys)}

RHESsys is a hydro-ecological model spatially distributed and designed to display the fluxes between the hydrological and vegetal processes in a basin [18]. The processes related to hydrological and biochemical aspects are combined and distributed spatially which allows the user to choose the size and shape of the modelled unities. The spatial partition of the landscape provides a useful tool to show the significant variations of those factors at different scales [19]. RHESsys can be defined as an ensamble of three models: MTN-Clim for aspects related with topography and meteorology, BIOME-BGC estimates storage and flux of carbon, nitrogen and water in an ecosystem and TOPMODEL for soil moisture and runoff. This model has been used to simulate the water inflow in Boadella-Darnius Dam. The model was calibrated for the 2002-2011 monthly flows. The calibration searches, on an iterative fashion, for the values of parameters that yield simulated flows more close to observed flows. In this study only two parameters were used: the decay of hydraulic conductivity with depth $(\mathrm{m})$ and saturated soil hydraulic conductivity at the surface - Ksat0 (K). The election of the best parameters is based on the result of three statistics defined in [20]; Nash-Sutcliffe efficiency index [21], Percent bias (PBIAS) and RMSE-observations standard deviation ratio (RSR). Once calibration is finished, an independent data period (1992-2001) was chosen for validation. This involved a comparison of simulated and observed flows with no longer parameter optimization (Figure 4).

\section{Results}

\subsection{Calibration and Validation of RHESsys}

The simulation shown on Figure 4 reveals that the magnitude, the evolution and variation in streamflows, are well reproduced. The validation shows a very good result except the period 19982000, where the streamflow is very low and the model tends to overestimate. In general, the statistics reveals that RHESsys reproduces accurately the dam inflow for the studied basin. 
The 1st International Electronic Conference on Hydrological Cycle (CHyCle-2017), 12 - 16 November 2017; Sciforum Electronic Conference Series, Vol. 1, 2017

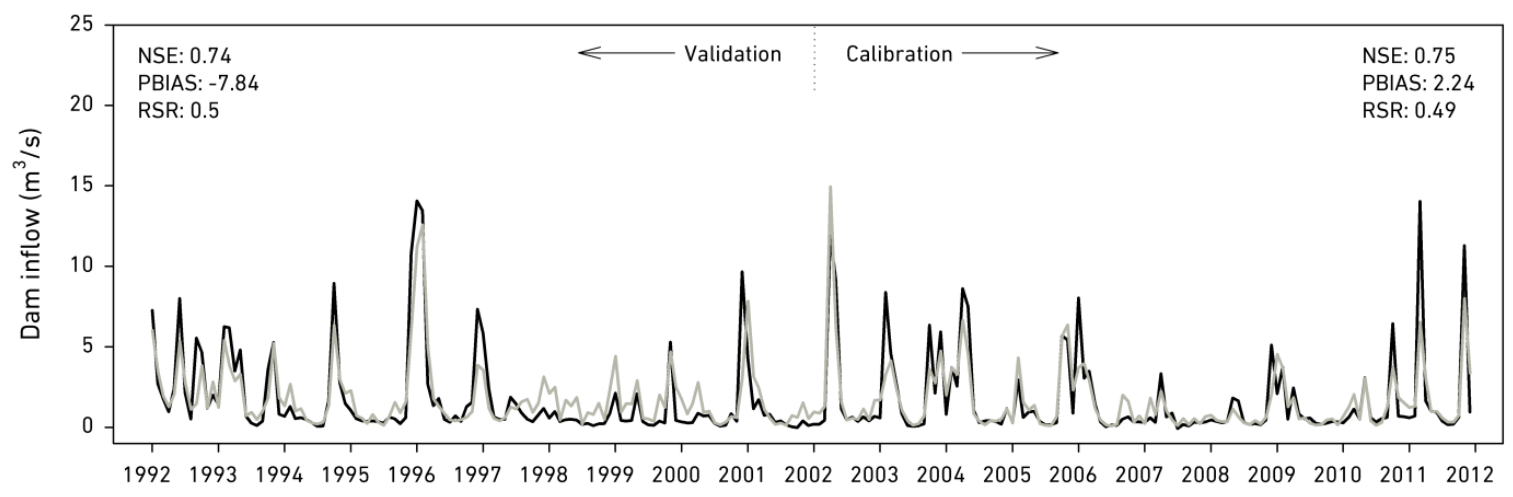

Figure 4. Simulated (grey) and Observed (black) monthly streamflow after parameter calibration.

\subsection{Inflow trends in Boadella-Darnius dam (1971-2050)}

Streamflow has clearly decreased since the 1970s to present (Table 2). An important streamflow reduction has been recorded, mainly in summer $(66.7 \%)$, spring $(33.3 \%)$ and winter $(30.8 \%)$ flows. The streamflow variability in these seasons also seems to be lower at the last decade of the observed period (2000-2012). At the annual scale the reduction of streamflow is also noticeable (-34.7\%). Table 2 also shows the simulation of dam inflow for 2012-2050 period. A generalized decrease is projected at annual scale $(-31.1 \%)$, similar to that for the observed period. It is noted that the summer streamflow will slightly decrease $(-4.5 \%)$ whereas winter and autum flows will experience greatest declines (63\% and $-42.1 \%$ respectively).

\begin{tabular}{cccccc}
\hline & winter & spring & summer & autumn & annual \\
\hline $1971-2011$ & $-30.8 \%$ & $-33.3 \%$ & $-66.7 \%$ & $-13.8 \%$ & $-34.7 \%$ \\
\hline $2012-2050$ & $-42.1 \%$ & $-4.5 \%$ & $-13.0 \%$ & $-63.0 \%$ & $-31.1 \%$ \\
\hline
\end{tabular}

Table 2. Observed and simulated seasonally inflow variation under climate and land-use change conditions

Figure 5 shows the mean monthly dam inflow simulated for the current, short-term and mid-term future periods, under climate change conditions (left plot) and under a combined action of climate and land-use change scenarios (rigth plot). The simulations under climate change conditions revealed a similar pattern with a general mean decrease of about $10 \%$ (spring, summer, winter) being higher in autumn for the mid-term period (-29.6\%). The combined action between climate and land-use changes shows a slightly larger decrease in streamflows. Thus, the mean decrease in spring, summer and winter is about $12-13 \%$, while in autumn reaches $-30 \%$ for the period $2041-50$. Table 3 shows the effect of climate and vegetation on the total water yield of the basin. A mean decrease of $11.1 \%$ and $14.7 \%$ on inflow is observed for short-term and mid-term time-windows without consideration of land-use changes. On the simulations where climate changes and land-use changes were combined 
The 1st International Electronic Conference on Hydrological Cycle (CHyCle-2017), 12 - 16 November 2017; Sciforum Electronic Conference Series, Vol. 1, 2017

the decrease projected for the same periods is $-11.9 \%$ and $-17 \%$ respectively.
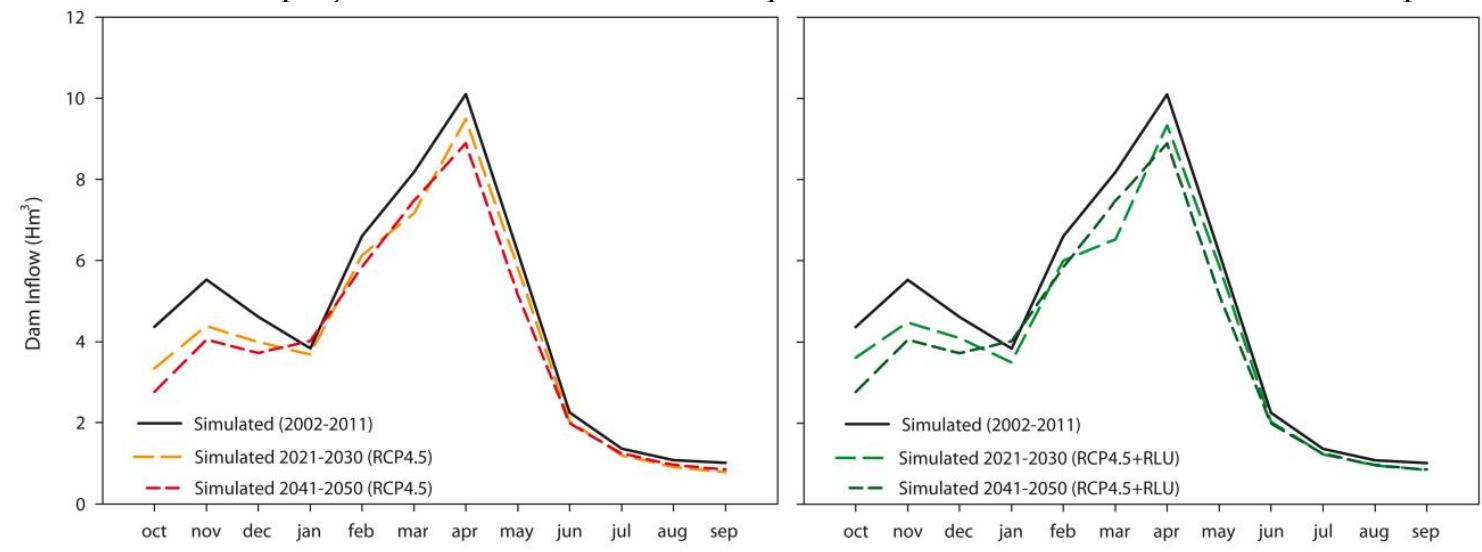

Months

Months

Figure 5. Mean seasonal Dam inflow for Simulated period for the current, short-term and mid-term future periods under climatic conditions (left) and under combined action of climatic and landuse change conditions (right).

\begin{tabular}{rlccc}
\hline & & $2002-2011$ & $2021-2030$ & $2041-2050$ \\
\hline \multirow{2}{*}{ RCP4.5 } & Dam Inflow $\left(\mathrm{Hm}^{3}\right)$ & $\mathbf{5 5 . 1}$ & 49.0 & $\mathbf{4 7 . 1}$ \\
\cline { 2 - 5 } & Variation $(\%)$ & & -11.1 & $\mathbf{- 1 4 . 7}$ \\
\hline \multirow{2}{*}{$\begin{array}{c}\text { RCP4.5 } \\
\text { RLU }\end{array}$} & Dam Inflow $\left(\mathrm{Hm}^{3}\right)$ & $\mathbf{5 5 . 1}$ & 48.6 & $\mathbf{4 5 . 8}$ \\
\cline { 2 - 5 } & Variation $(\%)$ & & -11.9 & -17.0 \\
\hline
\end{tabular}

Table 3. Mean annual storage capacity and variation for short-term and mid-term.

\subsection{Water management analysis}

A cluster analysis has been done as a method for identification of patterns in the water management of Boadella-Darnius dam according to methodology proposed by [22]. Variables to clusterize were monthly inflow, outflow and storage for every year. This allowed the characterization of three groups that describe how the reservoir is managed according to the inflow. 

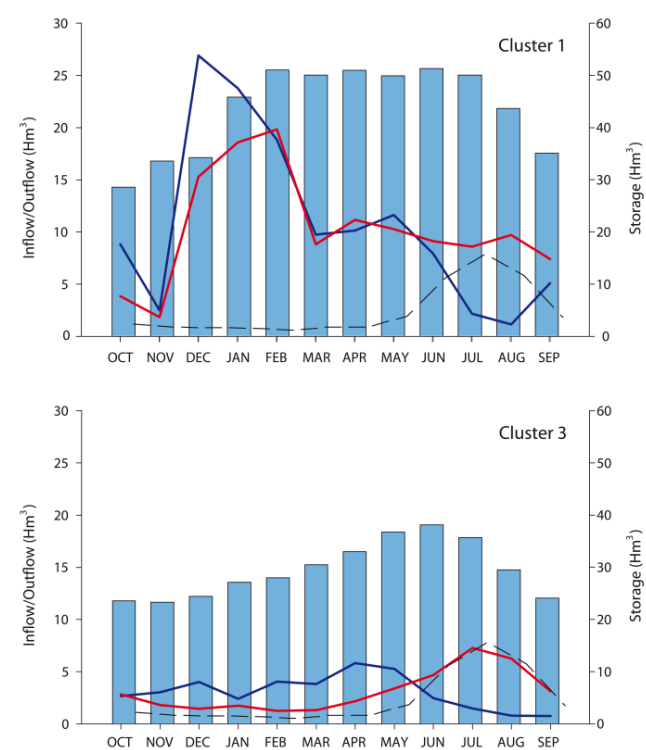
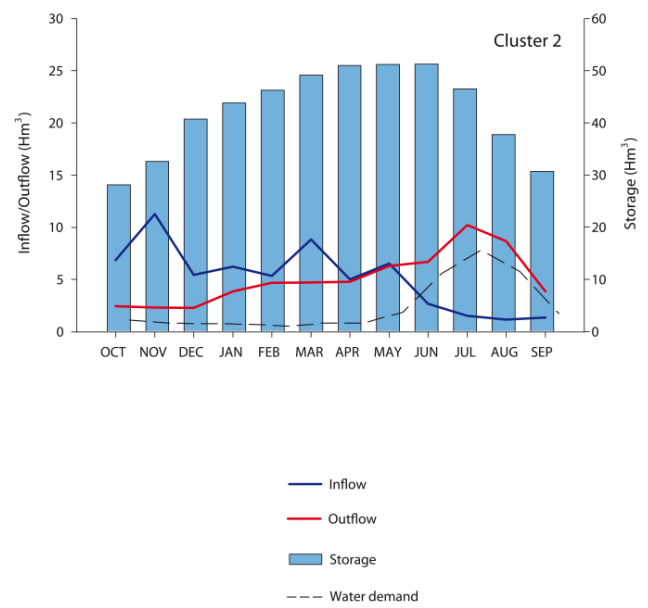

Figure 6. Boadella-Darnius dam water management: groups derived from a cluster analysis.

Figure 6 shows the three plausible water management ways obtained after a cluster process. Cluster 1 is characterized by high winter inflow, which determines a quick filling process of the dam whose storage is maintained at the maximum level during 6 months (February to July). Such management pattern makes it possible to provide water to satisfy the water demand in summer months. The pattern belonging to the second cluster group also reaches the maximum storage of the dam (at least 3 months) but, due to the inflow being lower than in Cluster 1, the outflow is maintained at low levels to allow gradually dam filling, in order to get the water amount needed for the summer. In the third case, the inflow is very low along the year, which leads to maintenance of the outflow at low values, just above the ecological streamflow along the most part of the year. Although the water demand is satisfied in summer, the dam storage is slightly above $20 \mathrm{hm}^{3}$ at the end of the year, which gives an idea of how the next hydrological campaign may be.

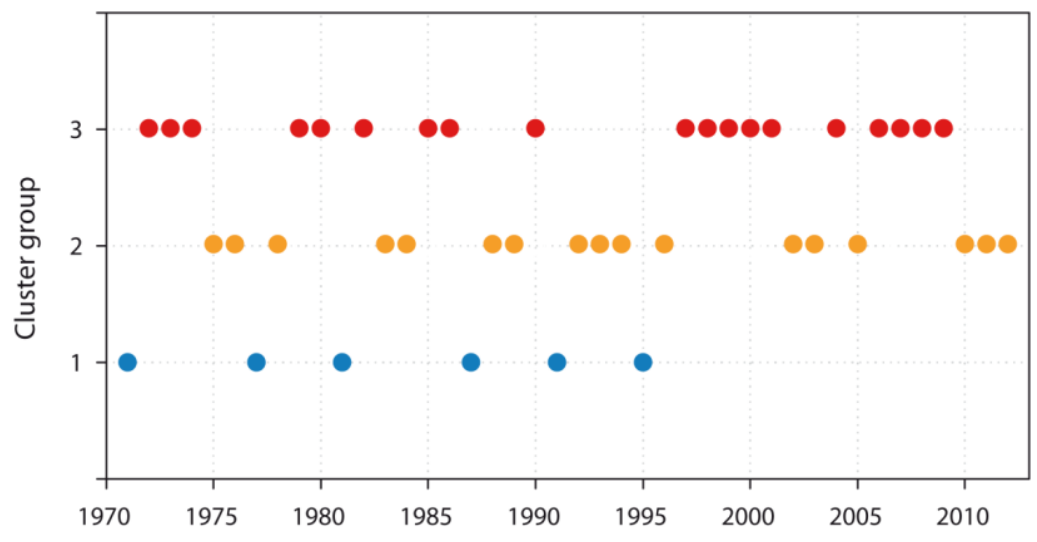

Figure 7. Annual distribution of cluster groups.

Figure 7 shows the distribution of the years on different cluster groups. Tow main periods are observed: (i) 1971-1995, where the cluster groups show an alternate pattern, and (ii) 1996-2012, where the frequency of third cluster group has increased and the first management pattern is no longer used. The cluster groups explain the different water management of Boadella-Darnius dam, which depends directly on the amount of water inflows into the dam. 
The 1st International Electronic Conference on Hydrological Cycle (CHyCle-2017), 12 - 16 November 2017; Sciforum Electronic Conference Series, Vol. 1, 2017
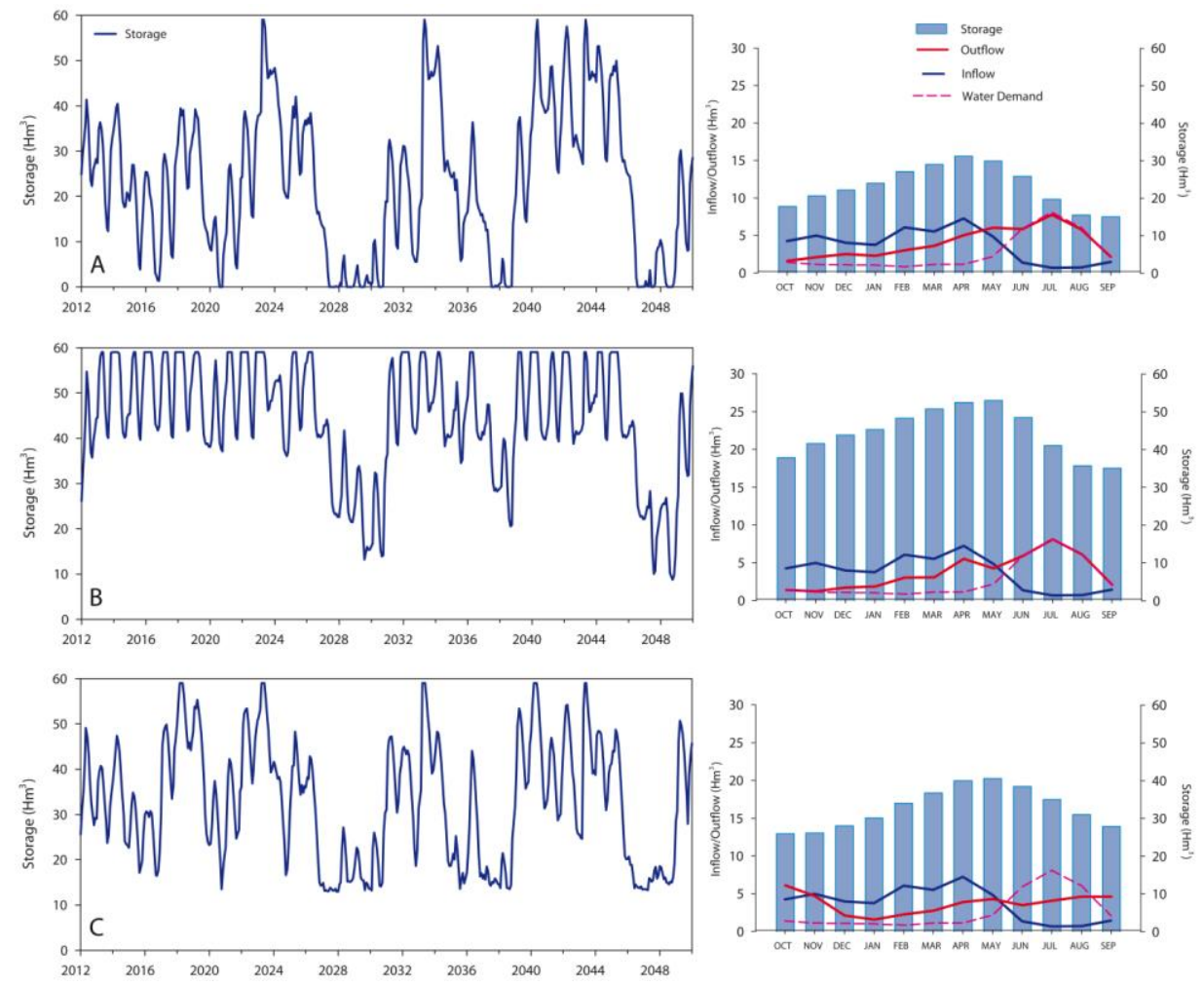

Figure 8. Monthly series simulated with different objectives in Boadella-Darnius dam: A) maintaining the actual outflow, B) maintaining the outflow as actual water demand; C) maintaining the water storage.

On Figure 8 the three different management practices are applied to simulated future inflows. On management $\mathrm{A}$ the outflow regime is unaltered in order to ensure the water demand. This management practice, asumming the inflows projected for the future, will periodically result in complete reservoir storage depletion. Management $B$ also guarantees the water demand and avoids storage depletion, but at the expense of the outflow, which would not reach the minimum ecological flow established by Catalan Water Agency [23]. Management C maintains the dam storage between $13 \mathrm{hm}^{3}$ and $59 \mathrm{hm}^{3}$, which are the 0.5 and 0.95 percentiles of the mean monthly storages for the calibration period (2002-2011), and it also preservs the minimum ecological flow downstream the dam. This management practice gets higher mean storages with some critical episodes but water demand is not always satisfied.

\section{Discussion and conclusions}

This study focuses on the water resources management under climate change and land-use scenarios for a mesoscale Mediterranean river basin. It shows how the decrease of discharge observed in the last decades $(-34.7 \%)$ and the trend expected for the short-term $(-11.9 \%)$ and mid-term $(-17 \%)$ future periods under climate and land-use changes, describing a scenario where the water management practices should be changed in order to satisfy the actual water demand if it is maintained and the minimum ecological flow established in [23]. The climate projections applied on this study are based on TICCC [12] which develops the indications suggested in the last report of the Intergovernmental Panel on Climate Change [14] using the representative concentration pathway (RCP) 4.5. Thus, it is established an increment of temperature between $+0.8^{\circ} \mathrm{C}$ and +1.4 and a decrease of precipitation in a range of $-2.4 \%$ and $-6.8 \%$. The changes on climate and land cover along the last decades and the expected ones for the future reveal a decrease on basins discharge within the Mediterranean area as 
The 1st International Electronic Conference on Hydrological Cycle (CHyCle-2017), 12 - 16 November 2017; Sciforum Electronic Conference Series, Vol. 1, 2017

is noted in many studies [1, 5, 24, 25, 26, 27, 28]. Many other studies also reflect that climate and landuse changes have a direct effect on discharge decrease [29, 30, 31, 32, 33].

In this study we revealed that the combined action of climate and land-use changes may have a negative effect on mean annual runoff $(\sim-30 \%)$ for the period 2012-2050. It is well known that the afforestation processes reduce the water availability $[34,35,36]$ and the obtained results are consistent with other studies in the Pyrenees. [33] showed a reduction of annual discharge for the period 20212050 of $-25 \%$ under climate conditions described in C4I model and a revegetation scenario. Processes of afforestation, as studied here, involves larger preciptiation interception by vegetation canopy and increasing water infiltration, which in turn decreases surface runoff. However, the magnitude of the vegetation effect in this basin is not very high as showed in Table 3. Other studies show a higher runoff decrease driven by vegetation $[27,33]$. This difference can be explained by a high density of forest in the study area, because the forest succession has developed gradually and because the landuse change proposed for this area is based on transition instead of revegetation. Aside from the climate and land-use change, also the increasing water demand will reduce the water resources as has already studied [10,14]. Boadella-Darnius reservoir is the main element to manage the water resources in Muga basin, so, the study and knowledge of its management practices are essential to determine what management scenarios may be plausible in the future. The distribution of cluster groups showed in Figure 6, which shows the increment of group 3 is highly related to drought periods studied in [37]. This reduction of dam inflow in the last decades and the expected negative trend for the first half of XXI century in the study area and in other catchments of the Mediterranean basin [38] determine that the policies on water management must improve the efficiency through methods that ensure the water availability for human activity but also for maintain the ecological river flow.

Although the construction of dams in the past was a solution for ensuring water supply during drought episodes, nowadays, with increasing water demand a new water management concept is needed. The drastic streamflow reduction in the last decades is accompanied by an increment of the water demand from industry, tourism and agricole uses. Thus, balance is almost every year negative and water management policies must be focused on increasing the efficiency of water use. The access to water resources in the Mediterrean often involve societal and political tensions, thus the strategies proposed by the scientific community, policy makers and stakeholders must be fluid and honest in order to find good and durable solutions.

Acknowledgments: We would like to thank the Spanish Meteorological State Agency (AEMET) and the Agència Catalana del Aigua (ACA) for providing the climatic and streamflow databases used in this study. This work has been supported by research project "LIFE12 ENV/ES/000536-Demonstration and validation of innovative methodology for regional climate change adaptation in the Mediterranean area (LIFE MEDACC)" financed by the LIFE programme of the European Commission.

\section{References}

1. Garcia-Ruiz J.M, López-Moreno J.I., Vicente-Serrano S.M., Lasanta-Martínez T., Begueria S., 2011. Mediterranean water resources in a global change scenario. 2011, Earth-Science Reviews, 105(3), 121-139.

2. EEA. 2012. Water resources in Europe in the context of vulnerability. EEA 2012 State of Water Assessment. EEA Report no. 11/2012. European Environmental Agency (EEA), Copenhagen. 
The 1st International Electronic Conference on Hydrological Cycle (CHyCle-2017), 12 - 16 November 2017; Sciforum Electronic Conference Series, Vol. 1, 2017

3. Iglesias, A., Garrote, L., Diz, A., Schlickenrieder, J., Martin-Carrasco, F. 2011. Re-thinking water policy priorities in the Mediterranean region in view of climate change. Environ. Sci. Pol. 14, 744-757.

4. Llamas, M.R., Custodio, E., de la Hera, A. and Fornés, J.M. 2015. Groundwater in Spain: increasing role, evolution, present and future. Environmental Earth Sciences, 73 (6), 2567-2578.

5. Lorenzo-Lacruz, J., Vicente-Serrano, S., López-Moreno, J.I., González-Hidalgo, J.C., MoránTejeda, E., Zabalza, J. 2012. Recent trends in Iberian streamflows (1945-2005), Journal of Hydrology, 414-415, 463-475.

6. Brunet, M., O. Saladié, Jones, P., Sigró, J., Aguilar, E., Moberg, A., Lister, D., Walther, A. Lopez, D. and Almarza C. 2006. The development of a new dataset of Spanish daily adjusted temperature series (SDATS) (1850-2003), International Journal of Climatology, 26, 1777-1802.

7. García-Ruiz, J.M. and Lana-Renault, N. 2011. Hydrological and erosive consequences of farmland abandonment in Europe, with special reference to the Mediterranean region - A review. Agriculture, Ecosystems and Environment, 140 (3-4), 317-338.

8. López-Moreno, J.I., Beninston, M. and García-Ruiz, J.M. 2008. Environmental change and water management in the Pyrinees: Facts and future perspectives for Mediterranean mountains. Global and Planetary Change, 61, 300-312.

9. Wang, K., Dickinson, R.E. and Shunlin, L. 2012. Global Atmospheric Evaporative Demand over Land from 1973 to 2008. Journal of Climate, 25, 8353:8361.

10. Vicente-Serrano, S.M., Zabalza-Martínez, J., Borràs, G., López-Moreno, J.I., Plá, E., Pascual, D. Savé, R., Biel, C., Funes, I., Azorín-Molina, C., Sánchez-Lorenzo, A., Martín-Hernández, N., Peña-Gallardo, M., Alonso-González, E., Tomas-Brugera, M. and El Kenawy, A. 2017. Extreme hydrological eventes and the influence of reservoirs in a highly regulated river basin of northeastern Spain. Journal of Hydrology: Regional Studies, 12, 13-32.

11. Morán-Tejeda, E., Lorenzo-Lacruz, J., López-Moreno, J. I., Rahman, K., \& Beniston, M. 2014. Streamflow timing of mountain rivers in Spain: recent changes and future projections. Journal of hydrology, 517, 1114-1127.

12. Martín-Vide, J. (coord) (2016). Tercer informe sobre el canvi climatic a Catalunya (Tercer informe sobre el cambio climático en Cataluna) (Barcelona, 2016, ISBN 978-84-9965-317-4 [IEC] -ISBN 978-84-393-9448-8 [Generalitat de Catalunya]).

13. Vicente-Serrano, S.M., Beguería, S., Juan I. López-Moreno, Miguel A. García-Vera y P. Stepanek. 2010. A complete daily precipitation database for North-East Spain: reconstruction, quality control and homogeneity. International Journal of Climatology, 30, 1146-1163.

14. IPCC, 2014: Climate Change 2014: Synthesis Report. Contribution of Working Groups I, II and III to the Fifth Assessment Report of the Intergovernmental Panel on Climate Change [Core Writing Team, R.K. Pachauri and L.A. Meyer (eds.)]. IPCC, Geneva, Switzerland, 151 pp.

15. Panagos Panos. The European soil database. 2006. GEO: connexion, 5 (7), 32-33. 
The 1st International Electronic Conference on Hydrological Cycle (CHyCle-2017), 12 - 16 November 2017;

Sciforum Electronic Conference Series, Vol. 1, 2017

16. Panagos P., Van Liedekerke M., Jones A., Montanarella L. 2012. European Soil Data Centre: Response to European policy support and public data requirements. Land-use Policy, 29 (2), 329-338.

17. Gracia C., Ibàñez J.J., Burriel J.A., Mata T., Vayreda J. (2000-2004). Inventari Ecològic i Forestal de Catalunya. CREAF, Bellaterra. ISBN de la sèrie: 84-931323-0-6.

18. Tague, C.L., Band, L.E. 2004a. RHESsys: Regional Hydro-Ecologic Simulation System-An objected-oriented approach to spatially distributed modeling of carbon, water and nutrient cycling. Earth Interact, 8, 1-42.

19. Band, L.E., Patterson, P., Nemani, R. and Running, S.W. 1993. Forest ecosystem processes at the watershed scale: incorporating hillslope hydrology. Agricultural and Forest Meteorology, 63, 93-126.

20. Moriasi, D.N., Arnold, J.G., Van Liew, M.W., Bingner, R.L., Harmel, R.D. and Veith, T.L. 2007. Model evaluation guidelines for systematic quantification of accuracy in watershed simulations. American Society of Agricultural and Biological Engineers, 50(3), 885-900.

21. Nash, J. E. and J. V. Sutcliffe. 1970. River flow forecasting through conceptual models part I - A discussion of principles. Journal of Hydrology, 10 (3), 282-290.

22. López-Moreno, J.I., Beguería, S. and García-Ruiz, J.M. 2004. The management of a large Mediterranean reservoir: storage regimens of the Yesa reservoir, Upper Aragon River Basin, Central Spanish Pyrenees. Environmental Management, 34: 508.

23. Agència Catalana de l'Aigua - Water Catalan Agency (ACA). Plan de Gestión de Cuenca del distrito fluvial de Cataluña, Generalitat de Catalunya, Barcelona, 2016.

24. Beguería, S., López-Moreno, J.I., Lorente, A., Seeger, M. and García-Ruiz, J.M. 2003. Assessing the effect of climate oscillations and land-use changes on streamflow in the Central Spanish Pyrenees. Ambio, 32 (4), 283:286.

25. Batalla, R.J., Gómez, C.M. and Kondolf, G.M. 2004. Reservoir-induced hydrological changes in the Ebro River basin (NE Spain). Journal of Hydrology, 290 (1-2), 117-136.

26. Gallart, F., and Llorens, P. 2004. Observations on land cover changes and water resources in the headwaters of the Ebro catchment, Iberian Peninsula. Physics and Chemistry of the Earth, $29,769-773$.

27. López-Moreno, J.I., Zabalza, J., Vicente-Serrano, S.M., Revuelto, J., Gilaberte, M., AzorínMolina, C., Morán-Tejeda, E., García-Ruiz, J.M. and Tague, C.L. 2014. Impact of Climate and land-use change on water availability and reservoir management: Scenarios in the Upper Aragón River, Spanish Pyrenees. Science of the Total Environment, 493, 1222-1231.

28. Collet, L., Ruelland, D., Borrell-Estupina, V., Dezetter, A. and Servat, E. 2013. Integrated modelling to assess long-term water supply capacity of a meso-sclae Mediterranean catchment, Science of the Total Environment. 461-462, 528-540.

29. Hu Q., Willson G.D., Chen X., Akyuz A. 2004. Effects of climate and land cover change on stream discharge in the Ozark Highlands, USA. Environmental Modelling and Assessment, 10. 9-19. 
The 1st International Electronic Conference on Hydrological Cycle (CHyCle-2017), 12 - 16 November 2017;

Sciforum Electronic Conference Series, Vol. 1, 2017

30. Tague, C., McMichael, C., Hope, A., Choate, J. and Clark, R. 2004b. Application or the RHESSYS model to a California semiarid shurbland watershed. Journal of the American water resources association. Doi: 10.1111/j.1752-1688.2004.tb04444.x

31. Kim, J., Choi, J., Choi, C. and Park, S. 2013. Impacts of changes in climate and landuse/land cover under IPCC RCP scenarios on streamflow in the Hoeya River Basin, Korea. Journal of the Total Environment, 452-453, 181-195.

32. Cuo, L., Zhang, Y., Gao, Y., Hao, Z. and Cairang, L. 2013. The impacts of climate change and land cover/use transition on the hydrology in the upper Yellow River Basin, China, Journal of Hydrology, 502, 37-52.

33. Morán-Tejeda, E., Zabalza, J., Rahman, K, Gago-Silva, A., López-Moreno, J.I., VicenteSerrano, V., Lehmann, A., Tague, C.L. and Beniston, M. 2014. Hydrological impacts of Climate and land-use changes in a mountain watershed: uncertainty estimation based on model comparison. Ecohydrology. DOI: 10.1002/eco.1590

34. Weatherheada EK, Howden NJK. 2009. The relationship between land-use and surface water resourcesin the UK. Land-use Policy, 265, 243-50.

35. Warburton ML, Schulze RE, Jewitt GPW. 2009. Hydrological impacts of land-use change in three diverse South African catchments. Journal of Hydrology, 414-415, 118-35.

36. Zégre N, Skaugset AE, Som NA, McDonnell JJ, Ganio LM. 2010. In lieu of the paired catchment approach: hydrologic model change detection at the catchment scale. Water Resources Research, 46(11), W11544.

37. Bayés Bruñol, C., Ribas Palom, A. and Saurí Pujol, D. 2003. Sequías y prensa regional en la Cuenca del río Muga (Girona). Geographicalia, 44, 123-144.

38. Milano, M., Ruelland, D., Dezetter, A., Fabre, J., Ardoin-Bardin, S. and Servat, E. 2013. Modelling the current and future capacity of water resources to meet water demands in the Ebro basin. Journal of Hydrology, 500, 114-126. 